\title{
Sciendo
}

DOI: $10.2478 /$ lpts-2019-0023

\section{OPTIMISATION OF PERMANENT MAGNETS OF BIOREACTOR MAGNETIC COUPLING WHILE PRESERVING THEIR EFFICIENCY}

\author{
M.Konuhova ${ }^{1}$, E.Kamolins ${ }^{1,2}$, S.Orlova ${ }^{1}$, A.Suleiko ${ }^{3}$, R.Otankis ${ }^{1}$ \\ ${ }^{1}$ Institute of Physical Energetics, \\ 11 Krivu Str., Riga, LV-1006, LATVIA \\ e-mail: mkonuhova@gmail.com \\ ${ }^{2}$ Riga Technical University \\ 12/1 Azenes Str., Riga, LV-1048, LATVIA \\ ${ }^{3}$ Latvian State Institute of Wood Chemistry \\ 27 Dzerbenes Str., Riga, LV-1006, LATVIA
}

The paper discusses issues related to the optimisation of magnetic couplings used in bioreactors (manufactured by JSC "Biotehniskais Centrs"). The purpose of optimisation was to preserve the maximum breakaway torque of the magnetic coupling while reducing the mass of rare earth elements used in its structure. The paper presents the rationale for the selected optimisation option taking into account the economic aspect. To solve the optimisation problem, the factors affecting the maximum torque of the magnetic coupling, such as the shape and height of the internal and external magnets, the angle of the external and internal magnets, as well as the height of the internal and external yoke, were determined. The design of the existing magnetic coupling was optimised and its prototype was made based on the results of optimisation. The results obtained by means of optimisation were compared with the results obtained experimentally by testing the manufactured prototype.

Keywords: bioreactors, design optimisation, industrial application, magnetic device, modelling, test bench

\section{INTRODUCTION}

European manufacturers of biotechnological equipment are increasingly using mixers with magnetic coupling. Bioreactors are used in biotechnological processes aimed at producing biopharmaceuticals. Many medical drugs obtained this way contribute to an increase in the expectancy of healthy life. Moreover, it should be noted that many of these drugs can only be obtained using biotechnological methods. Biotechnological processes for the production of these drugs usually meet the requirements of good manufacturing practice (GMP). In this case, the magnetic coupling is used in bioreactors to ensure sterile mixing of nutrient media [1], [2]. In 
addition to ensuring sterility, the mixers must provide high performance, i.e. having a sufficient maximum torque, which is ensuring the necessary mixing intensity. Therefore, designing high performance equipment is a relevant objective at the moment.

Magnetic couplings (MC) with permanent magnets are known to be able to transmit torque through the magnetic forces between the internal and external rotors (Fig. 1). In this type of MC its driving and driven parts are hermetically separated. At the same time, the transmission of vibration torque is very low due to the lack of mechanical feedback [3]. Magnetic coupling has one particularly valuable feature: it can operate with classical types of electric motors, while the motor is placed outside the operation area of the coupling. The application of magnetic couplings is continuously expanding; this is facilitated by the production of up-to-date permanent magnets (PM) based on rare earth elements. Magnetic couplings have one more important feature: they protect the mechanism from overload, as in case of operational overload of the driven part, magnetic connection between the rotors is terminated and the motor does not go into short-circuit fault mode.

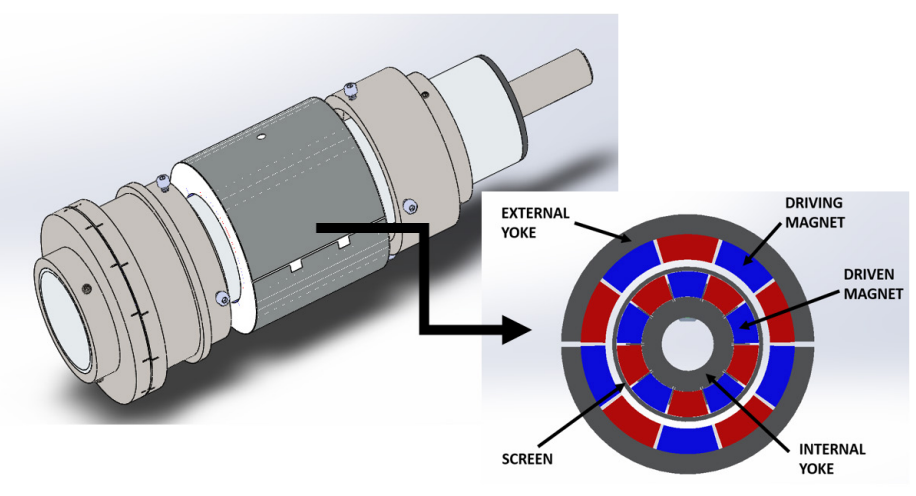

Fig. 1. Magnetic coupling of a bioreactor.

JSC "Biotehniskais Centrs" produces magnetic couplings for bioreactors of different volumes $\left(5 \mathrm{dm}^{3}, 1 \mathrm{~m}^{3}, 4 \mathrm{~m}^{3}, 15 \mathrm{~m}^{3}\right.$, etc. $)$. In this paper, we review in detail the design of the magnetic coupling for $1 \mathrm{~m}^{3}$ bioreactor with an average diameter of the air gap $D_{\delta \text { avg }}=60 \mathrm{~mm}$.

\section{INITIAL BIOREACTOR MAGNETIC COUPLING}

The bioreactor magnetic coupling with an average diameter of the air gap $D_{\delta \text { avg. }}=60 \mathrm{~mm}$ has the following design parameters:

- $\quad$ External radius, $R_{l}=40.5 \mathrm{~mm}$;

- $\quad$ Air gap, $\delta=4.11 \mathrm{~mm}-4.76 \mathrm{~mm}$;

- $\quad$ PM type $-\mathrm{N} 48 \mathrm{H}\left(t_{\max }=120^{\circ} \mathrm{C}\right)$;

- $\quad$ PM axial length, $l=3 \times 25.4=76.2 \mathrm{~mm}$;

- Internal and external PM height, $h_{P M}=6.35 \mathrm{~mm}$;

- Internal and external PM width, $b_{P M}=12.7 \mathrm{~mm}$; 
- $\quad$ Number of pole pair, $p=5$;

- $\quad$ PM manufacturer $-K \& J$ magnetics;

- $\quad$ PM remanence, $B_{r}=1.36 \mathrm{~T}$;

- $\quad$ PM coercivity, $H_{c}=907183 \mathrm{kA} / \mathrm{m}$.

The initial dimensions of the magnetic coupling are shown in Fig. 2a. As it can be seen from Fig. 2, the coupling has 10 magnets placed on the inner yoke and 10 magnets placed on the outer yoke. All magnets are made on the basis of rare earth elements $\mathrm{NdFeB}(\mathrm{N} 48 \mathrm{H}$ magnets) and have the same size and rectangular shape. Magnetization of magnets of this shape is linear and is carried out throughout the whole thickness (T) of the magnet (Fig. 2b). The air gap in the design varies between $4.11 \mathrm{~mm} \div 4.76 \mathrm{~mm}$, depending on the rotation of the internal rotor relative to the external one.

a.

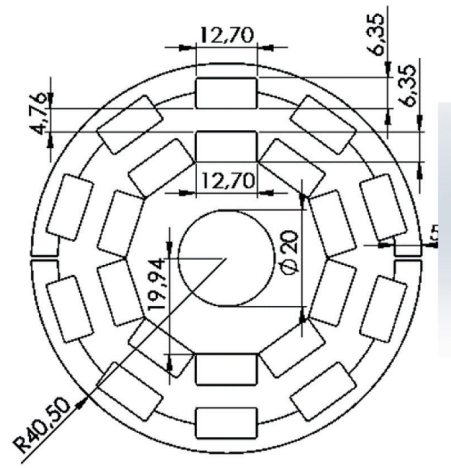

b.

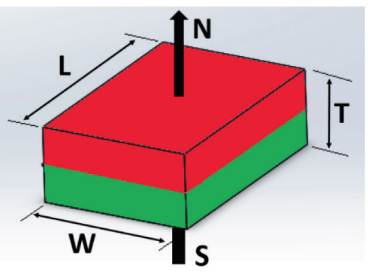

Fig. 2. a) Cross-section of magnetic coupling with rectangular magnets; b) Direction of magnetization of rectangular magnets (T- thickness, W-width, L-length, N-north pole, S-south pole).

Magnetic field of the coupling when the internal rotor is rotated to an angle $\theta=0^{\circ}$ and an angle $\theta=18^{\circ}$ is depicted in Fig. 3. The $\theta$ angle is the angle of shift between the inner and outer rotors. The angle $\theta=18^{\circ}$ is the rotation angle at which the magnetic coupling torque is at the maximum, and the angle $\theta=0^{\circ}$ corresponds to the minimum value of the torque.

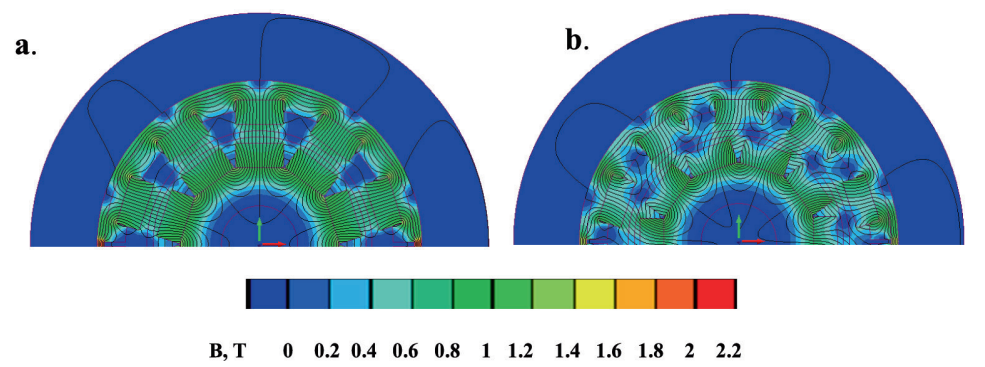

Fig. 3. Magnetic field of the coupling with rectangular magnets: a) $\theta=0^{\circ}$; b) $\theta=18^{\circ}$.

According to the results of numerical modelling based on the finite element method (FEM), the maximum torque of $\mathrm{MC}$ is $M_{\max \bmod }=50.2 \mathrm{Nm}$, and the maximum experimentally obtained torque is $M_{\text {max_exp }}=49.075 \mathrm{Nm}$. 
The specific torque of permanent magnets is calculated by the equation:

$$
M_{\text {spec.t._N } N \text { FeB }}=\frac{M_{\max }[N \cdot \mathrm{m}]}{G_{N_{\text {dFeB_total }}[\mathrm{kg}]}}=[\mathrm{N} \cdot \mathrm{m} / \mathrm{kg}],
$$

where $M_{\max }$ - maximum torque of $\mathrm{MC}, \mathrm{Nm}$;

$G_{\text {NdFeB_total }}$ - total magnet mass, $\mathrm{kg}$.

There are many factors affecting the maximum torque (Fig. 4).

\section{Factors affecting the value of MC maximum torque}
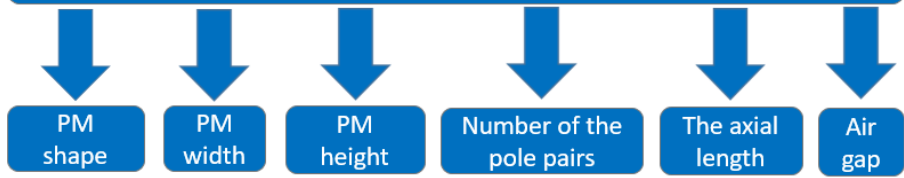

Fig. 4. Factors affecting the value of magnetic coupling maximum torque.

All of these factors affecting the maximum torque were taken into account in optimisation of the magnetic coupling design. However, it should be noted that when optimising the design focused on an increase in the maximum torque, an increase in the mass of magnets cannot be avoided, and this in turn will lead to a rise in the cost of production [4]. In this regard, the main optimisation objective was to preserve the value of the coupling maximum torque, while reducing the volume of rare earth elements (permanent magnets) in the design. The rationale for this optimisation solution is presented in Section 3.

\section{SELECTION OF OPTIMISATION METHOD AND ITS RATIONALE}

Rare earth elements such as neodymium and dysprosium are used in $\mathrm{NdFeB}$ magnet structure. However, the supply of these elements mainly depends on China. In 2018, according to statistical estimates, the world reserves were 120 million tons, most of which were located in China, i.e. about 44 million tons (Fig. 5).

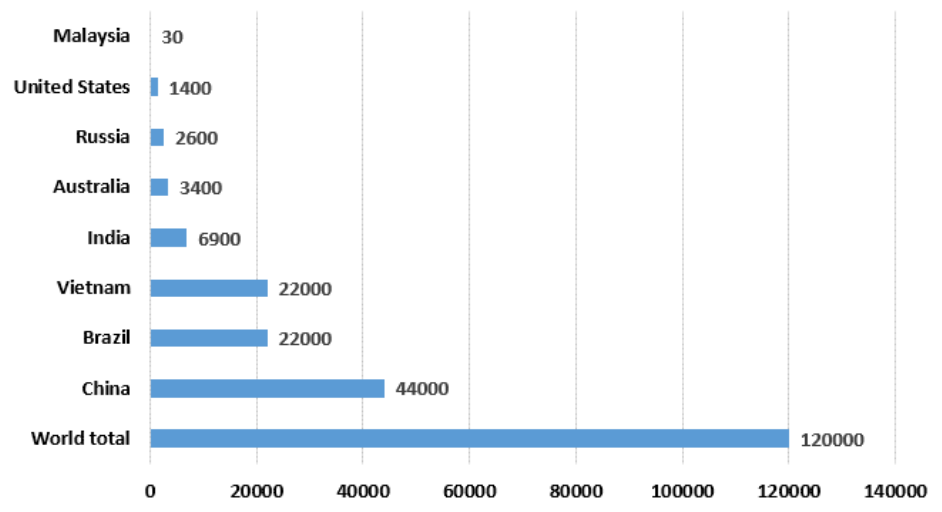

Fig. 5. Rare earth reserves worldwide as of 2018, by country (in thousand tons). 
How much the world depends on Chinese rare earth elements became clear at the end of 2010, when China threatened to limit the supplies. The price increase of rare earth elements was very significant, for example, the cost of neodymium and dysprosium increased about 25 times. Prices for most of the elements have declined significantly since 2012, but there is a big doubt about the future availability and price of rare earth magnets. Many experts anticipate supply shortage of some rare earth metals in the future, as demand is expected to exceed the industry's capacity to produce these rare earth elements over time. It is expected that the price of neodymium will reach about 104549 USD per ton in 2020, and in 2025 it is expected that the price will grow up to more than 148 thousand USD per ton [5].

Even such global scale manufacturers as Tesla, Inc. are concerned about the current situation regarding the rise in prices for rare earth elements, which may affect the price of production of electric vehicles [6].

Therefore, in this context, the main objective is to optimise the magnetic coupling in order to reduce the volume of rare earth elements for the production of magnetic couplings, while maintaining its maximum torque, since the rejection of permanent magnets is not possible.

Considering the above-mentioned facts, the purpose of optimisation was related to the economic effect.

\section{OPTIMISATION AND ITS RESULTS}

Many analysis models for electrical machines are based on FEM instead of the analytical model and equivalent circuit model. Therefore, intelligent optimisation algorithms have been employed for the optimisation of electrical machines in the past several decades, such as the evolutionary algorithms (EAs), particle swarm optimisation (PSO) algorithms, estimation of distribution algorithms (EDAs), immune algorithms, and ant colony algorithms, and their improvements. For the widely used genetic algorithm (GA) and differential evolutional algorithm (DEA), they are two of four major subclasses of EAs. The other two subclasses are evolution programming and evolution strategy [7].

For MC optimisation Mentor (A Siemens Business) software OptiNet in conjunction with MagNet was applied. To solve the optimisation problem, an evolutionary algorithm had been selected. It is obvious that the classical approach has a large number of algorithms and is constantly being developed by mathematicians; however, these algorithms usually give one solution.

Optimisation using a genetic algorithm results in obtaining a set of solutions with the best one being selected. The evolutionary algorithm preserves the population of solutions throughout the optimisation process; therefore, many solutions are obtained at the end of the optimisation process. For the multi-criteria optimisation, it is better to obtain a set of solutions instead of one, and as a result, evolutionary algorithm is a more useful approach [8].

To optimise the magnetic coupling, the following parameters have been selected: height of the inner yoke $\left(h_{\text {int } j}\right)$, height of the outer yoke $\left(h_{\text {ext }}\right)$, height of internal and external magnets $\left(h_{\text {int_PM }} h_{\text {ext } P M}\right)$, angle of internal and external magnets 
$\left(\alpha_{P M}\right)$, while the average diameter of the air gap remained unchanged $D_{\delta \text { avg }}=60 \mathrm{~mm}$.

As a result of the optimisation of the magnetic coupling, the transition from the rectangular shape of the magnets to the arc-shaped was carried out, thereby ensuring the uniformity of the air gap, the height of the internal and external magnets was significantly reduced, and the height of the internal and external yoke obtained its optimal value.

The optimisation results are presented in Table 1, which also shows the parameters of the initial coupling and the results of comparing the initial design and the coupling structure after optimisation.

Table 1

Summary of $1 \mathrm{~m} 3$ Bioreactor Magnetic Coupling Optimisation Results

\begin{tabular}{|c|c|c|c|}
\hline Parameters & $\begin{array}{c}\text { Initial } \\
\text { (numerical modelling) }\end{array}$ & $\begin{array}{c}\text { After optimisation } \\
\text { (numerical modelling) }\end{array}$ & Comparison \\
\hline External radius, $\mathrm{mm}$ & 40.5 & 44.23 & $+9.2 \%$ \\
\hline Coupling axial length, mm & 76.2 & 76.2 & \\
\hline Air gap, mm & $4.11-4.76$ & 4.11 & \\
\hline PM type & $\mathrm{N} 48 \mathrm{H}\left(\mathrm{t}_{\max }=120^{\circ} \mathrm{C}\right)$ & $\mathrm{N} 48 \mathrm{H}$ & \\
\hline PM axial length, mm & $3 \times 25.4=76.2$ & $3 \times 25.4=76.2$ & \\
\hline External PM height, mm & 6.35 & 4.44 & $-43 \%$ \\
\hline Internal PM height, $\mathrm{mm}$ & 6.35 & 4.4 & $-44 \%$ \\
\hline External PM width, mm & 12.7 & & \\
\hline Internal PM width, mm & 12.7 & & \\
\hline Internal PM angle, deg & - & 31 & \\
\hline External PM angle, deg & - & 34.56 & \\
\hline Number of pole pairs & 5 & 5 & \\
\hline PM manufacture & K\&J magnetics & K\&J magnetics & \\
\hline $\mathrm{PM}$ remanence, $\mathrm{T}$ & 1.36 & 1.36 & \\
\hline $\mathrm{PM}$ coercivity, $\mathrm{kA} / \mathrm{m}$ & 907183 & 907183 & \\
\hline PM density, $\mathrm{kg} / \mathrm{m}^{3}$ & 7500 & 7500 & \\
\hline PM total mass, $\mathrm{kg}$ & 0.919 & 0.844 & $-8.88 \%$ \\
\hline Maximum torque $\mathrm{M}_{\max }, \mathrm{Nm}$ & 50.2 & 56.07 & $+11.69 \%$ \\
\hline $\mathrm{PM}$ specific torque, $\mathrm{Nm} / \mathrm{kg}$ & 54.6 & 66.43 & $+21.66 \%$ \\
\hline
\end{tabular}

Coupling design and size are presented in Fig. 6.

Images of the magnetic field of the optimised magnetic coupling when the internal rotor is rotated by an angle of $\theta=0^{\circ}$ (minimum torque value) and an angle of $\theta=17^{\circ}$ (maximum torque value) are presented in Fig. 7. 

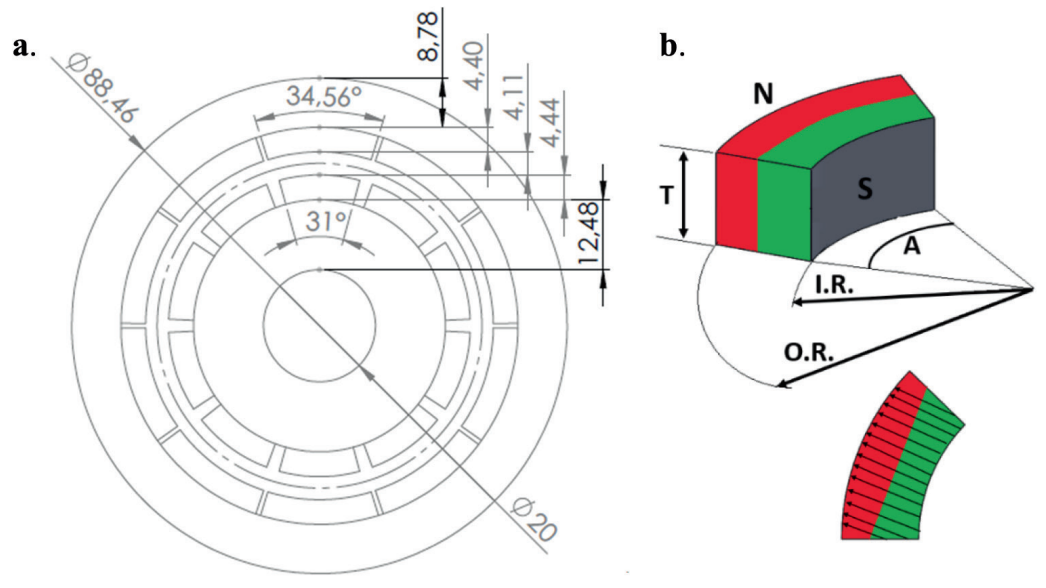

Fig. 6. a) Cross-section of magnetic coupling with arc-shaped magnets after optimization; b) Magnetization of arc-shaped K\&J magnets (T- thickness, A-angle, I.R.-inner radius, O.R.-outer radius, $\mathrm{N}$-north pole, $\mathrm{S}$-south pole).
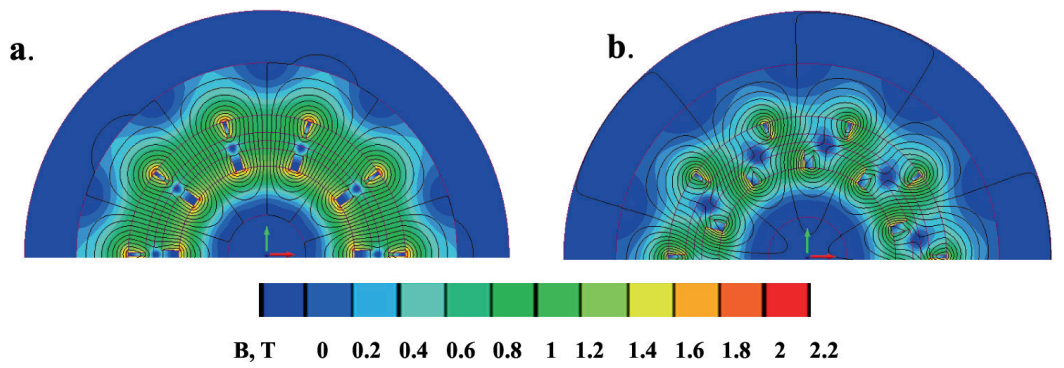

Fig. 7. Magnetic field of a coupling with arc-shaped magnets a) $\theta=0^{\circ}$; b) $\theta=17^{\circ}$.

As a result of the design optimisation, the value of the maximum torque of the initial coupling was increased by $11.69 \%$ according to the results of numerical modelling, and the consumption of PM was reduced by $8.88 \%$. At the same time, the specific torque of the magnets increased by $21.66 \%$, according to the results of numerical modelling.

\section{EXPERIMENTAL STUDY}

A prototype magnetic coupling of $1 \mathrm{~m}^{3}$ bioreactor with the arc-shaped magnets with an average diameter of the air gap $D_{\delta \text { avg }}=60 \mathrm{~mm}$ that was constructed according to the optimisation result was tested in the study. Experimental studies of the prototype made it possible to verify the results obtained by numerical modelling. During the study, the maximum torque at which the "breakdown" of the magnetic coupling occurred was determined. The test bench is presented in Fig. 8. The test bench consists of an electric motor $\left(U_{M A X}-60 \mathrm{~V}, n_{\text {MAX }}-3350 \mathrm{rpm}\right)$ and a magnetic coupling. The operating voltage of motor is $24 \mathrm{~V}$, which corresponds to the $\mathrm{MC}$ 
rotational speed of $200 \mathrm{rpm}$. The measurements were made using a mass sensor (CAS, BCS-60BW), with the measurement range of $0 \mathrm{~kg}-60 \mathrm{~kg}$ and measurement accuracy of $\pm 0.005 \mathrm{~kg}$.

The inner rotor is turned by an angle measured with voltage sensor that is placed on the inner rotor and connected with oscilloscope. After fixing the turning angle, the interaction forces between the PMs on both rotors try to turn the outer rotor on which the support system 1 is mounted. When the outer rotor tries to rotate (white arrow), the pressure force $F$ is made by the arm of force $l=200 \mathrm{~mm}$ and measured by the sensor 2 (Fig. 8).

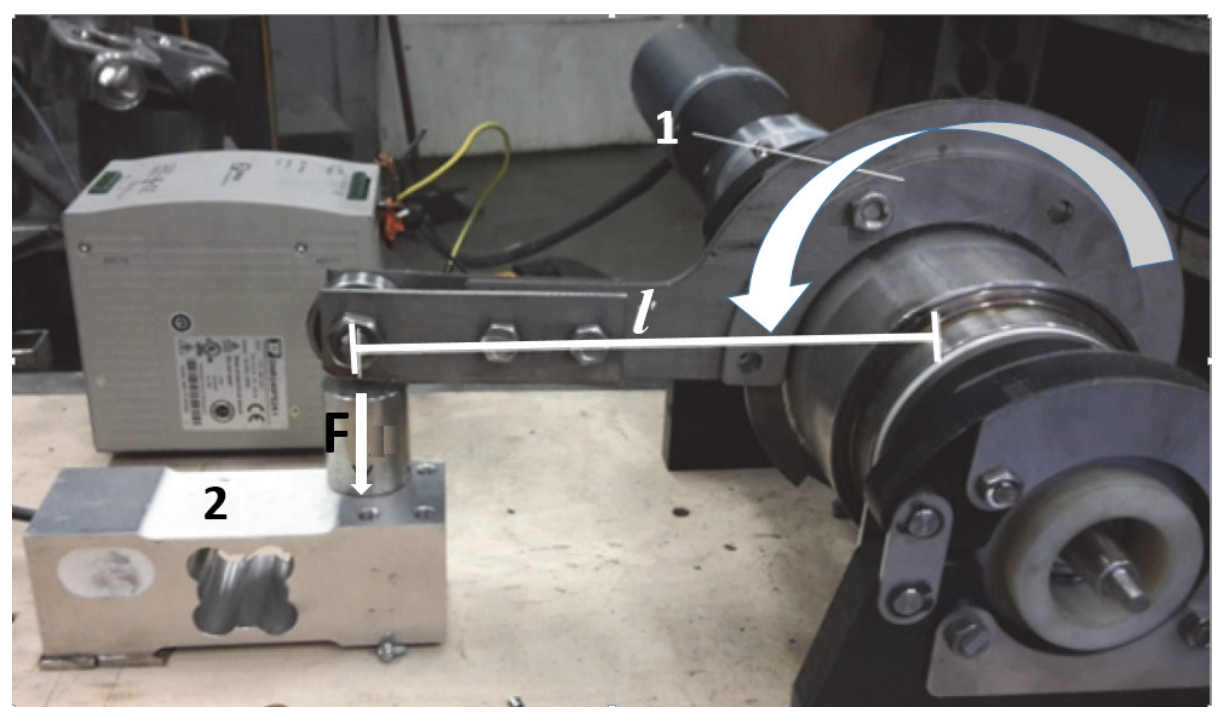

Fig. 8. Test bench.

The mechanical torque during the experiments was calculated from the mass readings as follows:

$$
T=m \cdot l \cdot g
$$

where $T$ - the mechanical torque generated on the mixers shaft, $m$ - the mass reading from the load cell, $l$ - the length of stainless steel rod, $g$ - constant of gravitational acceleration.

Table 2

The Results of Experimental Study

\begin{tabular}{|l|c|}
\hline Parameter & $1 \mathrm{~m}^{3}$ \\
\hline Maximum torque, Nm (experiment) & 49.69 \\
\hline
\end{tabular}




\section{COMPARISON OF NUMERICAL MODELLING RESULTS AND OPTIMISATION RESULTS}

Table 3 presents the values of the maximum and specific torque obtained theoretically and experimentally for the initial MC with rectangular magnets and the values of the maximum and specific torque of the new prototype with arc-shaped magnets.

Table 3

\section{Comparison of Numerical Modelling and Experimental Data}

\begin{tabular}{|l|c|c|c|}
\hline Parameters & Initial MC & Optimised MC & Comparison \\
\hline$M_{\text {max_mat.model. }}, \mathrm{Nm}$ & 50.2 & 56.07 & $+11.69 \%$ \\
\hline$M_{\text {max_exper. }}, \mathrm{Nm}$ & 49.075 & 49.69 & $+1.81 \%$ \\
\hline$M_{\text {specific_mat.model. }} \mathrm{Nm}$ & 54.6 & 66.43 & $+21.66 \%$ \\
\hline$M_{\text {specific_experim. }} \mathrm{Nm}$ & 53.40 & 58.87 & $+10.25 \%$ \\
\hline
\end{tabular}

The results obtained theoretically differ from the results obtained experimentally, which is explained by the features of actual assembled unit, as well as the error range of the measuring instruments. It should be noted that in the modelling all the parameters of the raw materials were obtained from the documentation provided by the supplier (manufacturer), without any additional assumptions by the researchers.

The difference in the torque values between the experimental study and numerical modelling can be explained by the fact that in actual $\mathrm{K} \& \mathrm{~J}$ magnets, the magnetization goes along the straight axis and is not radial (as it is considered in numerical modelling), the lines converge in the centre of the arc (Fig. 6b).

The specific torque of initial MC permanent magnets was increased by $21.66 \%$ being equal to $M_{\text {spec.t._NdFeB }}=66.43 \mathrm{Nm}$.

However, in spite of the difference of maximum torque obtained by theoretical and experimental studies, the mass of the magnets decreased by $8.88 \%$ in the new optimised $\mathrm{MC}$, and the new coupling, according to the experimental data, increased the value of the maximum torque by $1.81 \%$.

\section{CONCLUSIONS}

The study has revealed that the use of software based on FEM in conjunction with optimisation provides good results that can be fully applied in practice. Initially, the optimisation objective of reducing the mass of magnets was successfully completed, with maximum MC torque increase by $1.81 \%$, although originally the objective was simply not to reduce the available maximum torque value. The decrease in the mass of magnets used in the design by $8.88 \%$, taking into account the current increase in prices on the market of rare-earth elements, is significant. This kind of optimisation, based on the evaluation algorithm, can be surely applied to other magnetic couplings that use rare earth elements. 
As a recommendation, it can be noted that in the numerical modelling of magnetic couplings with arc-shaped magnets, it is possible to reduce the performance value of magnets by $5-10 \%$, which will bring the calculations to the actual figures, as magnetization of arc-shaped magnets occurs linearly, rather than along the arcshape.

\section{ACKNOWLEDGEMENTS}

The research has been supported by the European Regional Development Fund within the project "Influence of the Magnetic Field Initiated Stirring on Biotechnological Processes" No. 1.1.1.1/16/A/144.

\section{REFERENCES}

1. Jagani, N., Jagani, H., Hebbar, K., Gang, S.S., Vasanth Raj, P., Chandrashekhar, R.H., \& Rao, J. V. (2010). An overview of fermenter and the design considerations to enhance its productivity, Pharmacologyonline, 1, 261-301.

2. Varley, J., \& Birch, J. (1999). Reactor design for large scale suspension animal cell culture. Cytotechnology, 29, 177-205. doi:10.1023/A:1008008021481.

3. Li, Z., Wang, D., Zheng, D., \& Yu, L. (2017). Analytical modeling and analysis of magnetic field and torque for novel axial flux eddy current couplers with PM excitation. AIP Advanced, 7, 105303.

4. Orlova, S., Kamolins, E., Konuhova, M., \& Suleiko, A. (2018). Design of magnetic couplings for bioreactors: Analytical treatment and optimization. In: IEEE 2018 20th European Conference on Power Electronics and Applications (EPE'18 ECCE Europe), 17-21 September 2018, Riga, Latvia.

5. Statista. (n.d.). Rare earth reserves worldwide as of 2018, by country. https://www. statista.com/statistics/277268/rare-earth-reserves-by-country/

6. Desai, P. (2018). Tesla's electric motor shift to spur demand for rare earth neodymium. Reuters. Available at: https://www.reuters.com/article/us-metals-autos-neodymiumanalysis-idUSKCN1GO28I

7. Lei, G., Zhu, J., Guo, Y., Liu C., \& Ma, B. (2017). A review of design optimization methods for electrical machines. Energies 2017, 10, 1962.

8. Besnerais, J.L., Lanfranchi, V., Hecquet, M., \& Brochet, P. (2008). Multiobjective optimization of induction machines including mixed variables and noise minimization. IEEE Transactions on Magnetics, 44(6), 1102-1105. 


\title{
BIOREAKTORA MAGNĒTISKĀ SAJŪGA PASTĀVĪGO MAGNĒTU MASAS OPTIMIZĀCIJA, SAGLABĀJOT TĀS EFEKTIVITĀTI
}

\author{
M.Koṇuhova, E.Kamoliņš, S.Orlova, A.Šuleiko, R. Otaṇķis
}

Kopsavilkums

Šajā rakstā tiek aplūkoti jautājumi, kas saistīti ar bioreaktoros (JSC "Biotehniskais Centrs" production) izmantojamo magnētisko sajūga optimizēšanu. Optimizācijas mērķis bija saglabāt maksimālo magnētiskā sajūga "noraušanas" momentu, samazinot izmantojamo retzemju elementu (NdFeB) masu konstrukcijā. Rakstā aplūkots izvēètēà optimizācijas ceḷa pamatojums, ņemot vērā ekonomisko aspektu. Lai veiktu optimizāciju, tika noteikti faktori, kas ietekmē magnētiskā sajūga maksimālo momentu, tādi kā: iekšêjo un ārējo magnētu augstums un forma, iekšējo un ārējo magnētu leṇkisis, kā arī iekšèjā un ārējā jūga augstums. Tika veikta esošā magnētiskā sajūga konstrukcijas optimizācija un, pamatojoties uz veiktās optimizācijas rezultātiem, izgatavots tās prototips. Optimizācijas ceḷā iegūtie rezultāti tika salīdzināti ar rezultātiem, kas iegūti eksperimentālā ceḷā, testējot izgatavoto prototipu.

15.07.2019. 